\title{
Differences Between Right and Left Colon Cancers in Terms of Clinicopathological Features and Long-term Oncological Outcomes
}

\section{Sağ ve Sol Kolon Kanserleri Arasında Klinikopatolojik Özellikler ve Uzun Dönem Onkolojik Sonuçlar Açısından Farklılıklar}

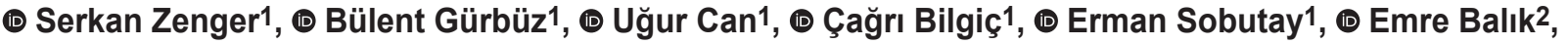 \\ (1) Dursun Buğra1
}

1VKF American Hospital, Clinic of General Surgery, İstanbul, Turkey

${ }^{2}$ Koç University Faculty of Medicine, Department of General Surgery, İstanbul, Turkey

\begin{abstract}
IIIIIIIII ABSTRACT
Aim: Although there are clinical differences in colon cancer (CC) according to the location of the tumor, the differences between right and left CC in terms of survival are not clear. Our aim was to analyze the clinicopathological differences between right and left CC and to investigate the effect of primary tumor location on recurrence and survival.

Method: The data of 330 patients who underwent curative surgery for right ( $\mathrm{n}=155)$ or left $(\mathrm{n}=175)$ colon cancer between 2011 and 2018 were retrospectively analyzed. Demographic characteristics, surgical data, pathological data, recurrence and survival rates of the patients were examined and the two groups were compared in terms of these parameters.

Results: Male to female ratio was significantly higher and operative time was significantly longer in the left CC than in the right CC. The mean number of harvested lymph nodes was significantly higher in the right CC than the left CC ( $32 \pm 3$ and $27 \pm 9$, respectively, p=0.001). Compared to patients with left CC, those with right CC had higher tumor diameter and tumor volume, had more poorly differentiation and tended to have more mucinous and medullary type cancer. As a result of a median follow-up of 54 months, it was determined that the 5-year overall survival in stage I-III patients was worse in the right CC than in the left CC. Especially in stage III patients, both overall and disease-free survival rates were found to be statistically significantly lower in the right CC compared to the left CC (In stage III disease, overall survival was 66.9\% in right CC and $81.8 \%$ in left CC, $\mathrm{p}=0.03$; disease-free survival was $54.2 \%$ in right CC and $70.6 \%$ in left CC, $\mathrm{p}=0.04$ ).

Conclusion: There may be clinicopathological and prognostic differences in CC depending on the location of the tumor. As a result of the long followup period in our case series, the prognosis in the right CC was worse, especially in stage III patients.
\end{abstract}

Keywords: Colon cancer, prognosis, tumor location, oncological outcomes

\section{|||||||||| ÖZ}

Amaç: Kolon kanserinde (KK) tümörün yerleşim yerine göre klinik farklar görülmesine rağmen sağkalım açısından sağ ve sol KK arasındaki değişiklikler tam olarak netlik kazanmamıştır. Amacımız; sağ ve sol KK'si arasındaki klinikopatolojik farklılıkları analiz etmek ve primer tümör yerleşiminin nükse ve sağkalıma etkisini araştırmaktır.

Yöntem: 2011-2018 tarihleri arasında, sağ (n=155) veya sol (n=175) kolon kanseri tanısıyla küratif cerrahi uygulanan 330 hastanın verileri retrospektif olarak incelendi. Hastaların demografik özellikleri, ameliyat verileri, patolojik verileri, nüks ve sağkalım oranları incelendi ve iki grup arasında karşılaştırmalar yapıldı.

Bulgular: Sol KK'sinde erkek/kadın oranı ve ameliyat süresi sağ KK'sine göre anlamlı derecede yüksekti. Çıkarılan ortalama lenf nodu sayısı sağ KK'inde sol KK'sine göre anlamlı derecede fazlaydı (32 \pm 3 ve $27 \pm 9$ sırasıyla, p=0,001). Ayrıca sağ KK'sinde tümör çapı ve tümör hacmi daha fazla, az diferansiyasyon oranı, müsinöz ve medüller kanser oranı sol KK'sine göre istatistiksel olarak anlamlı derecede daha yüksekti. Ortanca 54 ay takip sonucunda, evre 1-3 hastalarda 5 yıllık genel sağkalımın sağ KK’sinde daha kötü seyrettiği özellikle evre 3 hastalarda hem genel hem de hastalıksız

Address for Correspondence/Yazışma Adresi: Serkan Zenger, MD,

VKF American Hospital, Clinic of General Surgery, İstanbul, Turkey

E-mail: serkanzen@hotmail.com ORCID ID: orcid.org/0000-0003-2860-7413

Received/Geliş Tarihi: 08.04.2020 Accepted/Kabul Tarihi: 28.05.2020

${ }^{\circ}$ Copyright 2020 by Turkish Society of Colon and Rectal Surgery

Turkish Journal of Colorectal Disease published by Galenos Publishing House. 
sağkalım oranının sağ KK'sinde sol KK'sine göre istatiktiksel olarak anlamlı derecede düşük olduğu tespit edildi (Evre 3 genel sağkalım: sağ \%66,9 ve sol \%81,8, p=0,03; evre 3 hastalıksız sağkalım: sağ \%54,2 ve sol \%70,6, p=0,04).

Sonuç: Kolon kanserinde tümörün yerleșim yerine göre klinikopatolojik ve prognostik farklılıklar olabilir. Kendi serimizdeki uzun takip süresi sonucunda, sağ KK'sinde prognoz özellikle evre 3 hastalarda daha kötü seyretmektedir.

Anahtar Kelimeler: Kolon kanseri, prognoz, tümör yerleşim yeri, onkolojik sonuçlar

\section{Introduction}

Colon cancers (CC) are common types of cancer in both men and women. The World Health Organization has reported that there are 1.8 million new cases diagnosed as having colorectal cancer each year according to the GLOBOCAN 2018 database. ${ }^{1}$ For the first time, in 1990, Bufill et al. ${ }^{2}$ suggested that colon tumors might have biological and genetic differences according to their distal and proximal location. Colon is separated as right and left accepting the splenic flexure as the transition point. CCs of right and left colon develop from different carcinogenetic pathways and accordingly show different clinical, pathological and genetic features. $3,4,5$

Despite the described biological variety, the differences between the right and left CCs in terms of prognosis are not clear yet. In recent studies, it has been reported that the prognosis is worse in metastatic patients if the primary tumor is in the right colon. ${ }^{6,7,8,9}$ However, the effect of the location of the primary tumor on the prognosis in nonmetastatic patients is still controversial. $9,10,11,12,13,14$

In this study, our aim was to analyze the clinicopathological differences between right and left CCs and to investigate the effect of primary tumor location on recurrence and survival.

\section{Materials and Methods}

\section{Study Protocol}

In our study, prospectively collected data of 389 patients who underwent curative surgery with the diagnosis of CC between March 2011 and March 2018 in the General Surgery Clinic of the American Hospital were retrospectively analyzed. Fifty-nine patients who had hereditary cancers, synchronous tumors, tumors developed on the basis of inflammatory bowel disease, history of cancer, and underwent cytoreductive surgery were excluded from the study. Three hundred thirty patients operated with a diagnosis of right $(n=155)$ or left $(n=175)$ CC were included in the study. Written consent was obtained from all patients for surgery.

Right CC was defined cecum tumors, ascending colon tumors, hepatic flexure tumors or transverse colon tumors up to the splenic flexure, whereas left CC was defined splenic flexure tumors, descending colon tumors or sigmoid colon tumors up to rectosigmoid junction.
Preoperative staging was performed in all patients with colonoscopy, thorax and whole abdominal computed tomography and/or positron emission tomography. Patients who were eligible for surgery underwent curative surgery by the same surgeon (DB). In the right CC; right hemicolectomy, extended right hemicolectomy or subtotal colectomy was performed. In the left CC; left hemicolectomy, extended left hemicolectomy or anterior resection was performed. Patients who underwent simultaneous radical R0 liver surgery (resection, metastasectomy and/or radiofrequency ablation) and patients with omentum metastasis who underwent R0 omentum resection were also included in the study.

Demographic characteristics, surgical data, pathological data, recurrence and survival rates of the patients were examined and comparisons were made between the two groups. Pathology results were analyzed in terms of TNM stages, differentiation, histological type, tumor deposit, tumor perforation, lymphatic invasion, vascular invasion and perineural invasion, total number of harvested lymph nodes, tumor diameter and tumor volume, and the groups were compared statistically. Pathological examinations were performed by the same team experienced in gastrointestinal pathology.

\section{Postoperative Treatment and Follow-up}

Chemotherapy was applied to all stage III and IV patients. Chemotherapy was also applied to stage II patients with poor prognostic factors such as tumor at pathological T4 stage, perforation, obstruction, poor differentiation, presence of signet-ring cell component, lymphovascular or perineural invasion. Follow-up was performed every 3 months for the first 2 years after surgery, using physical examination, carcinoembryonic antigen, and imaging methods. In the next 3 years, follow-up was performed every 6 months.

Overall survival was defined as the time from surgery to death from any cause or to the last control date. Diseasefree survival was defined as the time from surgery to first recurrence proven radiologically or histopathologically or the time from surgery to death.

\section{Statistical Analysis}

Statistical analyzes were performed using SPSS version 24.0. Continuous variables were expressed as mean \pm standard deviation, and categorical variables as number (\%). Visual histograms and analytical tests (Shapiro-Wilk test or 
Kolmogorov-Smirnov test) were used to test the normal distribution of continuous variables. Descriptive statistics were used for the analysis of clinical and pathological parameters between the two groups formed according to tumor location. Categorical variables were compared using the chi-square test or Fisher's exact test. The independent samples t-test was used to compare the means of continuous variables with normal distribution between the two groups, or the Wilcoxon test when normal distribution was not met. Kaplan-Meier method was used for overall survival and disease-free survival analysis. Univariate and multivariate Cox regression analyses were used to determine independent predictors of overall survival and disease-free survival. A multivariate Cox regression model was created using parameters with $\mathrm{p}<0.05$ in univariate analyzes. For all analyzes, a p value less than 0.05 was considered significant.

\section{Results}

Male to female ratio was significantly higher in left CC compared to right CC (M/F: 2.2 and 1.1 respectively, $\mathrm{p}=0.005)$. There was no significant difference between the two groups in terms of mean age and body mass index. The number of ASA II patients in the left CC group and the number of ASA III patients in the right CC group were higher ( $\mathrm{p}=0.04)$. Laparoscopic surgery was performed in $78 \%$ of the patients in the right CC group and in $83.5 \%$ of the patients in the left CC group ( $>>0.05)$. The operative time was significantly longer in the left CC group compared to the right CC group (157 \pm 59 minutes and $142 \pm 53$ minutes, respectively, $\mathrm{p}=0.02$ ) (Table 1). Right hemicolectomy was performed in 126 (81.3\%) patients, extended right hemicolectomy in 21 (13.5\%) patients, and subtotal colectomy in $8(5.2 \%)$ patients in the right CC group. Anterior resection was performed in 116 (66.3\%) patients, left hemicolectomy in $55(31.4 \%)$ patients and extended left hemicolectomy in 4 (2.3\%) patients in the left CC group.

The mean number of harvested lymph nodes was significantly higher in the right CC group than the left CC group ( $32 \pm 3$ and $27 \pm 9$, respectively, $p=0.001)$. There was no difference between the two groups in terms of lymph node metastasis (right CC: $46.4 \%$ and left CC: $45.7 \%$ ). While there was no difference between the two groups in terms of the rates of TNM stages, it was determined that there were significant differences in terms of histological type and differentiation (Table 2). In the left CC group, $93.1 \%$ of the cancers were adenocarcinoma and $6.9 \%$ mucinous adenocarcinoma, while in the right CC group, $74.8 \%$ of the cancers were adenocarcinoma, $17.5 \%$ mucinous adenocarcinoma and $7.7 \%$ medullary carcinoma $(\mathrm{p}=0.001)$.

Table 1. Comparison of demographic characteristics and surgical data between right colon cancers and left colon cancers

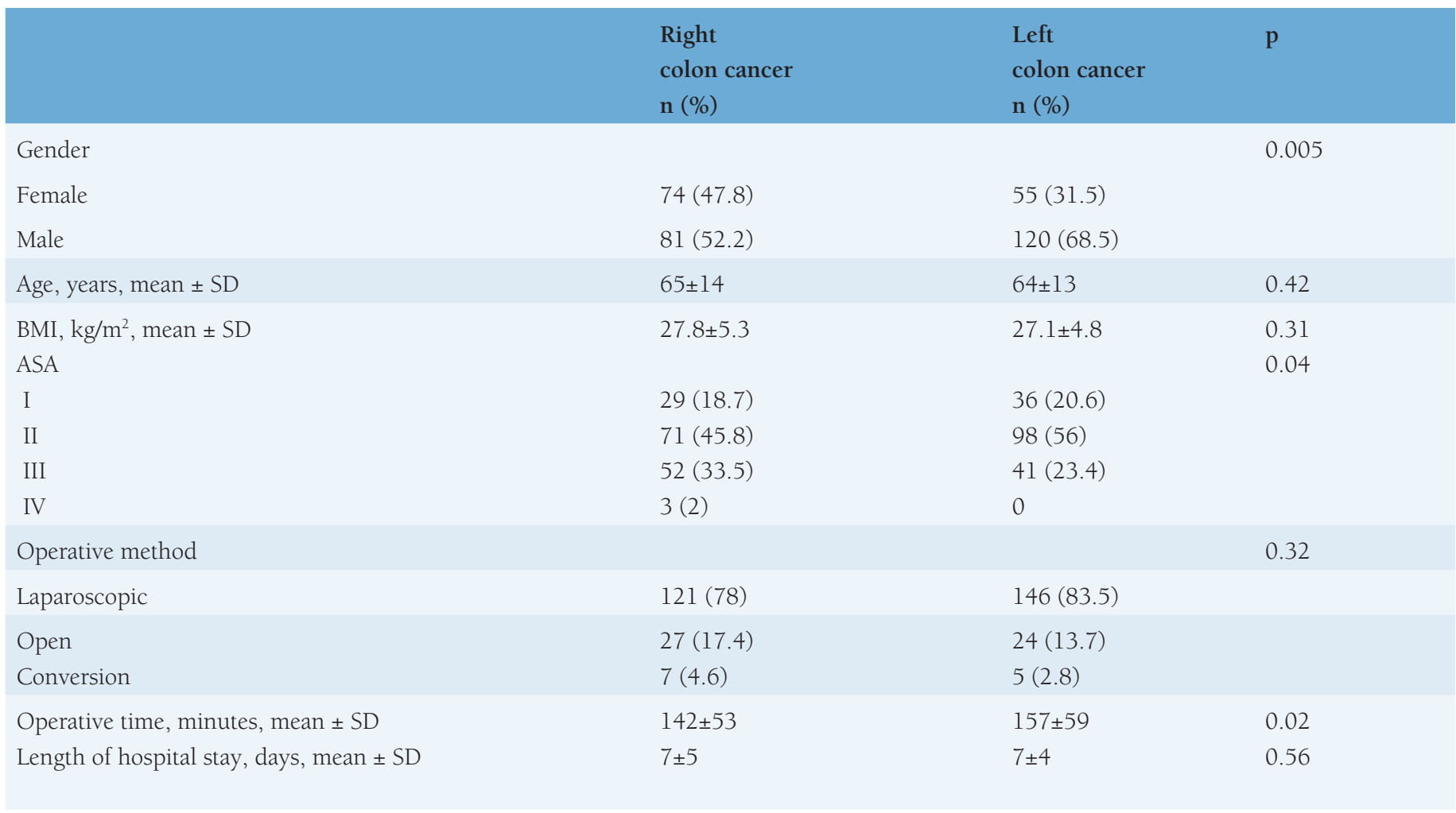


While the poor differentiation rate was higher in the right CC group, the well differentiation rate was higher in the left CC group ( $\mathrm{p}=0.04)$. Except that vascular invasion was more common in the left CC group, no difference was found between the two groups in terms of other prognostic factors (Table 2). Mean tumor diameter and tumor volume were also significantly higher in the right $\mathrm{CC}$ group $(\mathrm{p}=0.01$ and $\mathrm{p}=0.002$, respectively).

As a result of the median follow-up period of 54 months, it was determined that the 5-year overall survival and diseasefree survival in the right CC group in stage I-III patients were worse (Figure 1,2). When the survival analysis was performed according to the stages, although the 5-year overall survival and disease-free survival rates were lower in the right CC group compared to the left CC group in stage I and II patients, no statistically significant difference was found. However, the 5 year overall survival and diseasefree survival rates were found to be statistically significantly lower in the right CC group compared to the left CC group in stage III patients (overall survival rate was $66.9 \%$ in right CC group and $81.8 \%$ in left CC group, $\mathrm{p}=0.03$; disease-free survival rate was $54.2 \%$ in right CC group and $70.6 \%$ in left CC group, p=0.04) (Table 3, Figure 3, 4).

Table 2. Comparison of pathological data between right colon cancers and left colon cancers

\begin{tabular}{|c|c|c|c|}
\hline & $\begin{array}{l}\text { Right } \\
\text { colon cancer } \\
\text { n (\%) }\end{array}$ & $\begin{array}{l}\text { Left } \\
\text { colon cancer } \\
\text { n (\%) }\end{array}$ & $\mathrm{p}$ \\
\hline T stage & & & 0.59 \\
\hline $\mathrm{T} 1$ & $20(12.9)$ & $23(13.1)$ & \\
\hline $\mathrm{T} 2$ & $12(7.7)$ & $15(8.6)$ & \\
\hline T3 & $67(43.2)$ & $85(48.6)$ & \\
\hline $\mathrm{T} 4$ & $56(36.2)$ & $52(29.7)$ & \\
\hline Lymph node metastasis $(\mathrm{N}+)$ & $72(46.4)$ & $80(45.7)$ & 0.88 \\
\hline pTNM stage & & & 0.48 \\
\hline I & $26(16.8)$ & $29(16.6)$ & \\
\hline II & $58(37.4)$ & $61(34.8)$ & \\
\hline III & $56(35.4)$ & $55(31.5)$ & \\
\hline IV & $16(10.4)$ & $30(17.1)$ & \\
\hline Histologic type & & & 0.001 \\
\hline Adenocarcinoma & $116(74.8)$ & $163(93.1)$ & \\
\hline Mucinous adenocarcinoma & $27(17.5)$ & $12(6.9)$ & \\
\hline Medullary carcinoma & $12(7.7)$ & 0 & \\
\hline Differentiation & & & 0.04 \\
\hline Well & $13(8.4)$ & $25(14.3)$ & \\
\hline Moderate & $120(77.5)$ & $138(78.8)$ & \\
\hline Poor & $22(14.1)$ & $12(6.9)$ & \\
\hline Lymphatic invasion & $91(58.7)$ & $98(56)$ & 0.62 \\
\hline Vascular invasion & $39(25.1)$ & $66(37.7)$ & 0.02 \\
\hline Perineural invasion & $36(23.2)$ & $46(26.2)$ & 0.51 \\
\hline Tumor perforation & $18(11.7)$ & $18(10.2)$ & 0.58 \\
\hline Tumor deposit & $28(18.1)$ & $39(22.3)$ & 0.29 \\
\hline Harvested lymph nodes, mean \pm SD & $32 \pm 3$ & $27 \pm 9$ & 0.001 \\
\hline Tumor size, $\mathrm{cm}$, mean $\pm \mathrm{SD}$ & $4.7 \pm 2.6$ & $4 \pm 1.8$ & 0.01 \\
\hline Tumor volume, $\mathrm{cm}^{3}$, mean $\pm \mathrm{SD}$ & $70.9 \pm 141.4$ & $31.9 \pm 42.9$ & 0.002 \\
\hline Recurrence & $24(15.4)$ & $35(20)$ & 0.27 \\
\hline
\end{tabular}

SD: Standart deviation 


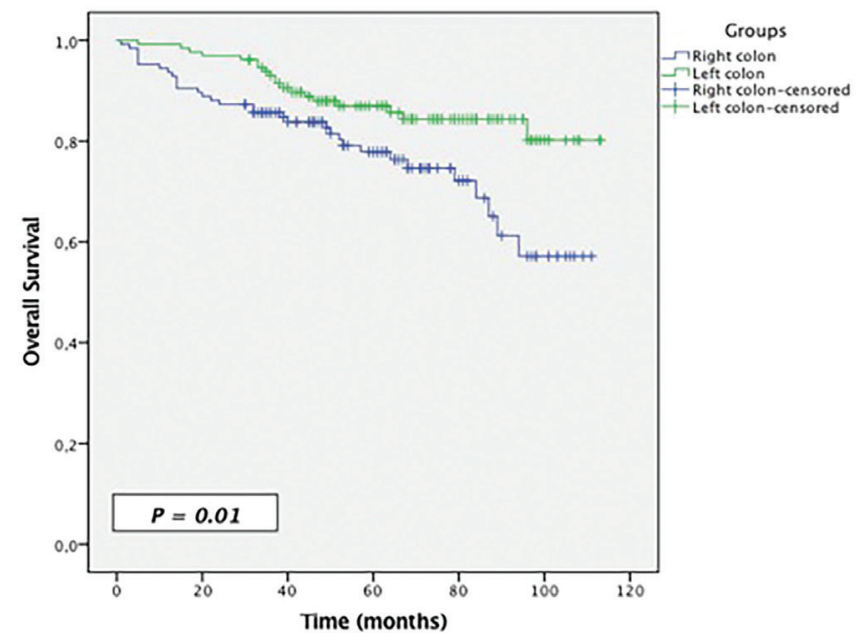

Figure 1. Kaplan-Meier curves for overall survival between right and leftsided colon cancers in stage I, II, and III

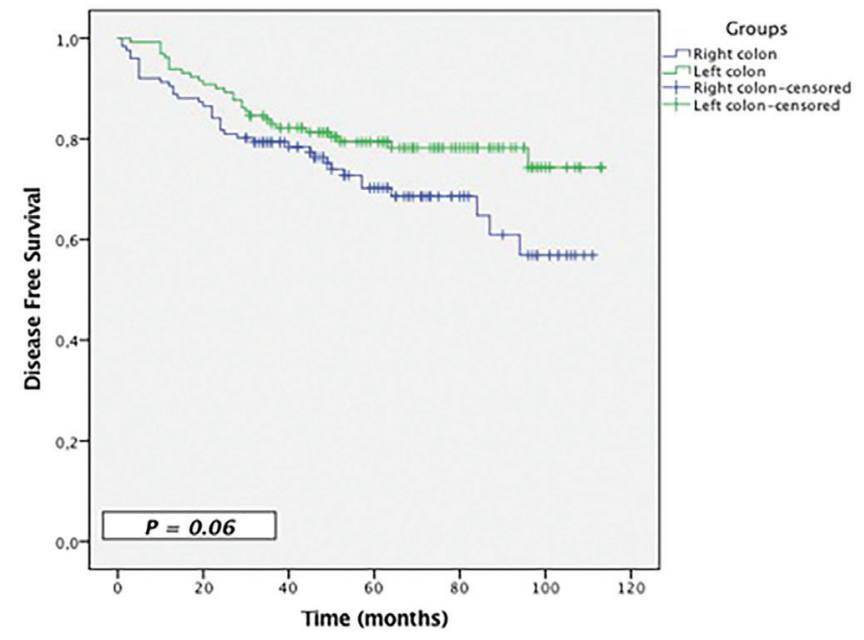

Figure 2. Kaplan-Meier curves for disease free survival between right and left-sided colon cancers in stage I, II, and III

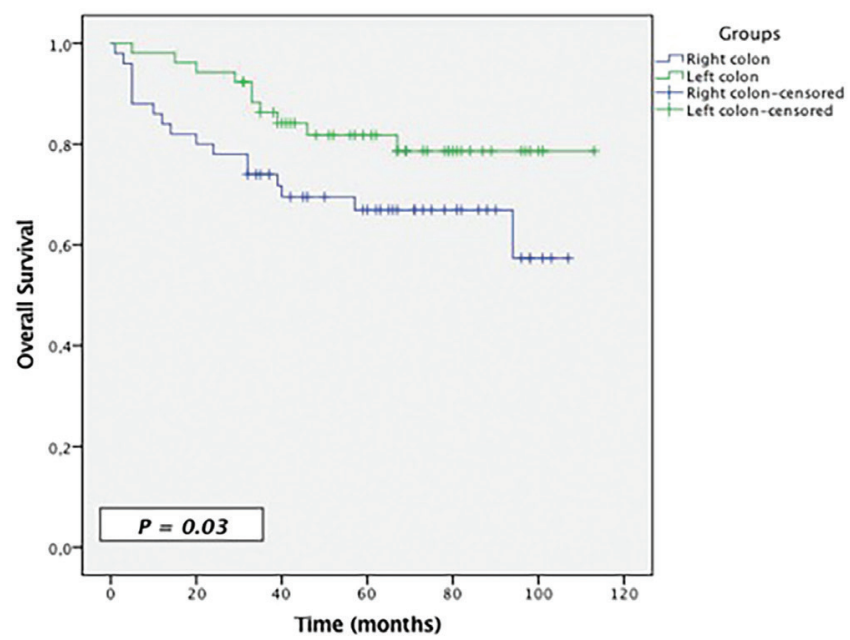

Figure 3. Kaplan-Meier curves for overall survival between right and leftsided colon cancers in stage III

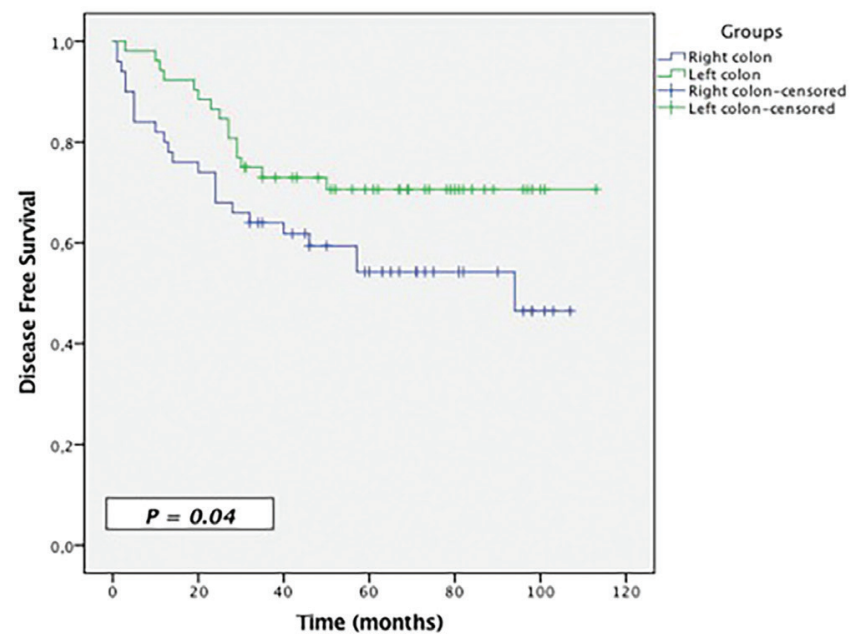

Figure 4. Kaplan-Meier curves for disease free survival between right and left-sided colon cancers in stage III

Table 3. Five year overall and disease-free survival rates on right colon cancer and left colon cancer

\begin{tabular}{|c|c|c|c|c|}
\hline & Stage & $\begin{array}{l}\text { Right colon cancer } \\
\text { 5-year survival (\%) }\end{array}$ & $\begin{array}{l}\text { Left colon cancer } \\
5 \text {-year survival (\%) }\end{array}$ & $\mathrm{p}$ \\
\hline \multirow[t]{6}{*}{ Overall survival } & All stages & 74.4 & 81.8 & 0.02 \\
\hline & I-III & 77.9 & 86.9 & 0.01 \\
\hline & I & 91.3 & 95.8 & 0.65 \\
\hline & II & 83 & 87.5 & 0.23 \\
\hline & III & 66.9 & 81.8 & 0.03 \\
\hline & IV & 40.4 & 54.9 & 0.41 \\
\hline \multirow[t]{6}{*}{ Disease-free survival } & All stages & 66.9 & 71.5 & 0.27 \\
\hline & I-III & 70.6 & 79.4 & 0.06 \\
\hline & I & 91.3 & 95.5 & 0.65 \\
\hline & II & 79.3 & 80.2 & 0.51 \\
\hline & III & 54.2 & 70.6 & 0.04 \\
\hline & IV & 34.6 & 43.8 & 0.67 \\
\hline
\end{tabular}


In the univariate analyzes performed in terms of the effect of prognostic factors on survival, it was found right CC, the presence of lymphatic, vascular and perineural invasion and the large tumor diameter had an effect on survival. In multivariate analyzes; it was found that advanced age, poor differentiation, tumor perforation, presence of tumor deposits, and large tumor volume significantly and negatively affected survival (Table 4).

\section{Discussion}

The proximal and distal parts of the splenic flexure are two different colon sections of which embryological origins are not the same. ${ }^{3}$ In CC, the location of the primary tumor creates clinical, pathological and genetic differences. ${ }^{3,4}$ Changes in molecular features may also cause this difference. ${ }^{15,16}$ It has been reported that microsatellite instability-high (MSI-H) ratio is significantly higher in the right $\mathrm{CC}$ and that it affects the treatment of stage II patients. ${ }^{15,17}$ BRAF mutation is also a poor prognostic factor associated with peritoneal carcinomatosis, which is more common in the right CC. ${ }^{18,19,20}$ In studies comparing two different tumor locations, it was reported that there were clinicopathological differences in right CC such as not very pronounced symptoms, higher rate of T4 stage, higher rate of poor differentiation and more common mucinous adenocarcinoma and medullary carcinoma, and female predominance. ${ }^{21,22}$ In the left CC, on the other hand, more pronounced symptoms, lower stage and chromosomal differences were observed. ${ }^{22,23,24}$ Although the reason for these changes between the two colon segments is not fully understood, different embryological origins are probably the most important factor. ${ }^{25}$ In our study, female/ male ratio, rate of poor differentiation, and rate of medullary carcinoma and mucinous adenocarcinoma were higher in right CC than left CC in accordance with the literature. In addition, tumor diameter was larger and tumor volume was higher in the right CC compared to the left CC.

However, a clear conclusion could not be reached in studies comparing the two groups in terms of survival. Many authors have stated that the prognosis of the right CC is worse. ${ }^{11,26,27}$ However, some studies have reported that the right CC has a better prognosis. ${ }^{9}, 12,13$ Weiss et al. ${ }^{13}$ reported in their survival analysis in 53,801 patients with stage I-III CC that there was no difference in terms of prognosis between right and left CCs when all stages were included and also only in stage I disease. In the same study, it was reported that right CC had a better prognosis than left CC in stage II disease [hazard ratio (HR) $=0.92 ; 95 \%$ confidence interval (CI): 0.87-0.97; $\mathrm{p}=0.001)$ ]; while in stage III disease, right CC had a worse prognosis (HR $=1.12$; 95\% CI: 1.06-1.18; $\mathrm{p}=0.001) .{ }^{13}$ In a study conducted by Warschow et al. ${ }^{12}$ in more than 90,000 patients, 5-year overall survival in the right CC in stage I and II patients (in stage I disease, $77.4 \%$ in right CC and $74.9 \%$ in left CC; in stage II disease; $68.3 \%$ in right CC and $63.9 \%$ in left CC) and cancer-specific survival (In stage I disease, $94 \%$ in right CC and $91.7 \%$ in left CC; in stage II disease; $84.6 \%$ in right CC and $80.1 \%$ in left CC) were reported to be better. In the same study, the

Table 4. Cox regression analyses for prognostic factors of overall survival

\begin{tabular}{|c|c|c|c|c|}
\hline \multirow{2}{*}{ Factors } & \multicolumn{2}{|l|}{ Univariate } & \multicolumn{2}{|l|}{ Multivariate } \\
\hline & HR (95\% CI) & $\mathrm{p}$ & HR (95\% CI) & $\mathrm{p}$ \\
\hline Female gender & $0.85(0.53-1.37)$ & 0.51 & - & - \\
\hline Age & $1.04(1.02-1.06)$ & 0.001 & $1.03(1.01-1.05)$ & 0.002 \\
\hline Right colon cancer & $1.62(1.03-2.56)$ & 0.03 & $1.47(0.89-2.42)$ & 0.13 \\
\hline Harvested lymph nodes & $0.98(0.96-1.01)$ & 0.14 & - & - \\
\hline Poor differentiation & $3.34(1.95-5.75)$ & 0.001 & $2.57(1.26-4.64)$ & 0.005 \\
\hline Lymphatic invasion & $2.91(1.72-4.89)$ & 0.001 & $1.69(0.91-3.12)$ & 0.11 \\
\hline Vascular invasion & $1.60(1.01-2.54)$ & 0.04 & $1.28(0.63-1.91)$ & 0.38 \\
\hline Perineural invasion & $2.41(1.52-3.79)$ & 0.001 & $1.37(0.82-2.47)$ & 0.25 \\
\hline Tumor perforation & $2.45(1.39-4.31)$ & 0.002 & $2.33(1.21-4.48)$ & 0.01 \\
\hline Tumor deposit & $2.57(1.58-4.16)$ & 0.001 & $2.05(1.18-3.58)$ & 0.01 \\
\hline Tumor size & $1.02(1.01-1.03)$ & 0.01 & $0.99(0.98-1.01)$ & 0.34 \\
\hline Tumor volume & $1.005(1.003-1.006)$ & 0.001 & $1.004(1.002-1.006)$ & 0.005 \\
\hline
\end{tabular}

CI: Confidence interval, HR: Hazard ratio 
prognosis in stage III patients was similar in both groups (overall survival; $53.3 \%$ in right CC and 52.9\% in left CC, cancer-specific survival; $63.6 \%$ in right CC and $64.6 \%$ in left CC). ${ }^{12}$ In the study conducted by Yang et al. ${ }^{9}$ in 57,847 patients, it was stated that the right CC had better cancerspecific survival in stage I and II patients, but it was worse in stage III patients. In a meta-analysis performed by Petrelli et al. ${ }^{28}, 66$ studies were included and it was found that left CC had a better prognosis (HR: 0.82; 95\% CI: 0.79-0.84; $\mathrm{p}<0.001$ ), and the location of the tumor was reported to be a prognostic criterion. In a study conducted by He et al. ${ }^{29}$ in 377,849 patients, it was stated that liver and lung metastases were more in the left $\mathrm{CC}$, but the prognosis was better than in the right $\mathrm{CC}$. In addition, there are studies showing that complete mesocolic excision technique has a positive effect on prognosis, especially in right CC, as well as studies reporting that it does not affect prognosis. ${ }^{30,31,32,33}$ In our study, while there was no statistically significant difference in terms of overall survival and disease-free survival in stage I and II patients, both overall survival and disease-free survival rates were statistically significantly worse in stage III patients with right CC compared to left CC patients.

There are some limitations in interpreting the results of this study. The first of these is the retrospective feature of the study. The genetic or molecular characteristics of all patients could not be examined and a comparison could not be made in this direction in terms of the two groups. MSI has been routinely evaluated in pathological examinations since 2015, but MSI could not be included in the comparison since this examination could not be performed in patients in the first years of the study. In addition, the fact that adjuvant chemotherapy protocols vary over the years and according to the oncologist is another limitation.

\section{Conclusion}

As a result, there might be clinicopathological and prognostic differences in CC depending on the location of the tumor. At the end of the long follow-up period in our series, it was found that, the prognosis in right CC was worse especially in stage III patients. We anticipate that the data obtained as a result of our study should be taken into account by the medical oncology department that we work together, in the selection and application process of adjuvant oncological treatments.

\section{Ethics}

Ethics Committee Approval: Retrospective study.

Informed Consent: Written consent was obtained from all patients for surgery.

Peer-review: Internally and externally peer review.

\section{Authorship Contributions}

Surgical and Medical Practices: S.Z., B.G., U.C., Ç.B., E.S., E.B., D.B., Concept: S.Z., B.G., E.B., D.B., Design: S.Z., U.C., D.B., Data Collection or Processing: S.Z., B.G., C..B., E.S., Analysis or Interpretation: S.Z., U.C., E.S., Literature Search: S.Z., B.G., Ç.B., Writing: S.Z., U.C., E.B., D.B.

Conflict of Interest: No conflict of interest was declared by the authors.

Financial Disclosure: The authors declared that this study received no financial support.

\section{References}

1. Ferlay J, Colombet M, Soerjomataram I, Mathers C, Parkin DM, Pineros M, Znaor A, Bray F. Estimating the global cancer incidence and mortality in 2018: GLOBOCAN sources and methods. Int J Cancer. 2019;144:19411953.

2. Bufill JA. Colorectal cancer: evidence for distinct genetic categories based on proximal or distal tumor location. Ann Intern Med. 1990;113:779-788.

3. Gervaz P, Bucher P, Morel P. Two colons-two cancers: paradigm shift and clinical implications. J Surg Oncol. 2004;88:261-266.

4. Shen H, Yang J, Huang Q, Jiang MJ, Tan YN, Fu JF, Zhu LZ, Fang XF, Yuan Y. Different treatment strategies and molecular features between right-sided and left-sided colon cancers. World J Gastroenterol. 2015;21:6470-6478.

5. Iacopetta B. Are there two sides to colorectal cancer? Int J Cancer. 2002; 101:403-408

6. Arnold D, Lueza B, Douillard JY, Peeters M, Lenz HJ, Venook A, Heinemann V, Van Cutsem E, Pignon JP, Tabernero J, Cervantes A, Ciardiello F. Prognostic and predictive value of primary tumour side in patients with RAS wild-type metastatic colorectal cancer treated with chemotherapy and EGFR directed antibodies in six randomized trials. Ann Oncol. 2017;28:1713-1729

7. Brule SY, Jonker DJ, Karapetis CS, O'Callaghan CJ, Moore MJ, Wong R, Tebbutt NC, Underhill C, Yip D, Zalcberg JR, Tu D, Goodwin RA. Location of colon cancer (right-sided versus left-sided) as a prognostic factor and a predictor of benefit from cetuximab in NCIC CO.17. Eur J Cancer. 2015:51:1405-1414.

8. Chen KH, Shao YY, Chen HM, Lin YL, Lin ZZ, Lai MS, Cheng AL, Yeh KH. Primary tumor site is a useful predictor of cetuximab efficacy in the third-line or salvage treatment of KRAS wild-type (exon 2 non-mutant) metastatic colorectal cancer: a nationwide cohort study. BMC Cancer 2016;16:327.

9. Yang J, Du XL, Li ST, Wang BY, Wu YY, Chen ZL, Lv M, Shen YW, Wang X, Dong DF, Li D, Wang F, Li EX, Yi M, Yang J. Characteristics of Differently Located Colorectal Cancers Support Proximal and Distal Classification: A Population-Based Study of 57,847 Patients. PLoS One. 2016;11:e0167540.

10. Yahagi M, Okabayashi K, Hasegawa H, Tsuruta M, Kitagawa Y. The Worse Prognosis of Right-Sided Compared with Left-Sided Colon Cancers: a Systematic Review and Meta-analysis. J Gastrointest Surg. 2016;20:648655.

11. Meguid RA, Slidell MB, Wolfgang CL, Chang DC, Ahuja N. Is there a difference in survival between right- versus left-sided colon cancers? Ann Surg Oncol. 2008;15:2388-2394.

12. Warschkow R, Sulz MC, Marti L, Tarantino I, Schmied BM, Cerny T, Guller U. Better survival in right-sided versus left-sided stage I - III colon cancer patients. BMC Cancer. 2016;16:554.

13. Weiss JM, Pfau PR, O'Connor ES, King J, LoConte N, Kennedy G, Smith MA. Mortality by stage for right- versus left-sided colon cancer: analysis of surveillance, epidemiology, and end results--Medicare data. J Clin Oncol. 2011;29:4401-4409. 
14. Keskin M, Sivriköz E, Yegen G, Bayraktar A, Kulle CB, Bugra D, Bulut MT, Balik E. Right vs Left Colon Cancers Have Comparable Survival: a Decade's Experience. Indian J Surg. 2019:1-8.

15. Missiaglia E, Jacobs B, D’Ario G, Di Narzo AF, Soneson C, Budinska E, Popovici V, Vecchione L, Gerster S, Yan P, Roth AD, Klingbiel D, Bosman FT, Delorenzi M, Tejpar S. Distal and proximal colon cancers differ in terms of molecular, pathological, and clinical features. Ann Oncol. 2014:25:1995-2001.

16. Nawa T, Kato J, Kawamoto H, Okada H, Yamamoto H, Kohno H, Endo $\mathrm{H}$, Shiratori Y. Differences between right- and left-sided colon cancer in patient characteristics, cancer morphology and histology. J Gastroenterol Hepatol. 2008;23:418-423.

17. Merok MA, Ahlquist T, Royrvik EC, Tufteland KF, Hektoen M, Sjo OH, Mala T, Svindland A, Lothe RA, Nesbakken A. Microsatellite instability has a positive prognostic impact on stage II colorectal cancer after complete resection: results from a large, consecutive Norwegian series. Ann Oncol. 2013;24:1274-1282.

18. Eklof V, Wikberg ML, Edin S, Dahlin AM, Jonsson BA, Oberg A, Rutegard J, Palmqvist R. The prognostic role of KRAS, BRAF, PIK3CA and PTEN in colorectal cancer. Br J Cancer. 2013;108:2153-2163.

19. Jang MH, Kim S, Hwang DY, Kim WY, Lim SD, Kim WS, Hwang TS, Han HS. BRAF-Mutated Colorectal Cancer Exhibits Distinct Clinicopathological Features from Wild-Type BRAF-Expressing Cancer Independent of the Microsatellite Instability Status. J Korean Med Sci. 2017;32:38-46.

20. Tran B, Kopetz S, Tie J, Gibbs P, Jiang ZQ, Lieu CH, Agarwal A, Maru DM, Sieber O, Desai J. Impact of BRAF mutation and microsatellite instability on the pattern of metastatic spread and prognosis in metastatic colorectal cancer. Cancer. 2011;117:4623-4632.

21. Zenger S, Gurbuz B, Can U, Bilgic C, Sobutay E, Postgil Yilmaz S, Balik E, Yalti T, Bugra D. Clinicopathological importance of colorectal medullary carcinoma. European Surgery. 2019;51:308-314.

22. Lee GH, Malietzis G, Askari A, Bernardo D, Al-Hassi HO, Clark SK. Is rightsided colon cancer different to left-sided colorectal cancer? - a systematic review. Eur J Surg Oncol. 2015;41:300-308

23. Gervaz P, Bouzourene H, Cerottini JP, Chaubert P, Benhattar J, Secic M, Wexner S, Givel JC, Belin B. Dukes B colorectal cancer: distinct genetic categories and clinical outcome based on proximal or distal tumor location. Dis Colon Rectum. 2001:44:364-372; discussion 372-363.
24. Hutchins G, Southward K, Handley K, Magill L, Beaumont C, Stahlschmidt J, Richman S, Chambers P, Seymour M, Kerr D, Gray R, Quirke P. Value of mismatch repair, KRAS, and BRAF mutations in predicting recurrence and benefits from chemotherapy in colorectal cancer. J Clin Oncol. 2011;29:1261-1270.

25. Benedix F, Kube R, Meyer F, Schmidt U, Gastinger I, Lippert H, Colon/ Rectum Carcinomas Study G. Comparison of 17,641 patients with rightand left-sided colon cancer: differences in epidemiology, perioperative course, histology, and survival. Dis Colon Rectum. 2010;53:57-64.

26. Jung MK, Shin US, Ki YJ, Kim YB, Moon SM, Sung SJ. Is the Location of the Tumor Another Prognostic Factor for Patients With Colon Cancer? Ann Coloproctol. 2017;33:210-218.

27. Suttie SA, Shaikh I, Mullen R, Amin AI, Daniel T, Yalamarthi S. Outcome of right- and left-sided colonic and rectal cancer following surgical resection. Colorectal Dis. 2011;13:884-889.

28. Petrelli F, Tomasello G, Borgonovo K, Ghidini M, Turati L, Dallera P, Passalacqua R, Sgroi G, Barni S. Prognostic Survival Associated With Left-Sided vs Right-Sided Colon Cancer: A Systematic Review and Metaanalysis. JAMA Oncol. 2017;3:211-219.

29. He XK, Wu W, Ding YE, Li Y, Sun LM, Si J. Different Anatomical Subsites of Colon Cancer and Mortality: A Population-Based Study. Gastroenterol Res Pract. 2018;2018:7153685.

30. Bertelsen CA, Neuenschwander AU, Jansen JE, Wilhelmsen M, KirkegaardKlitbo A, Tenma JR, Bols B, Ingeholm P, Rasmussen LA, Jepsen LV, Iversen ER, Kristensen B, Gogenur I, Danish Colorectal Cancer G. Disease-free survival after complete mesocolic excision compared with conventional colon cancer surgery: a retrospective, population-based study. Lancet Oncol. 2015;16:161-168.

31. Merkel S, Weber K, Matzel KE, Agaimy A, Gohl J, Hohenberger W. Prognosis of patients with colonic carcinoma before, during and after implementation of complete mesocolic excision. Br J Surg. 2016;103:12201229.

32. Agalianos C, Gouvas N, Dervenis C, Tsiaoussis J, Theodoropoulos G, Theodorou D, Zografos G, Xynos E. Is complete mesocolic excision oncologically superior to conventional surgery for colon cancer? A retrospective comparative study. Ann Gastroenterol. 2017;30:688-696.

33. Olofsson F, Buchwald P, Elmstahl S, Syk I. No benefit of extended mesenteric resection with central vascular ligation in right-sided colon cancer. Colorectal Dis. 2016;18:773-778. 